\title{
Faizal \& Shabana Foundation: A Venture Philanthropic Approach to Education
}

\author{
Sreevas Sahasranamam, Strathclyde Business School
}

Sumit Mitra, Indian Institute of Management Kozhikode

Accepted/In press - Emerald Emerging Market Case Studies

Government schools in India were famous for being ramshackle and dingy, thus not providing the most ideal of atmospheres conducive for learning. Faizal Kottikollon, the founding chairman of Faizal and Shabana Foundation (F\&SF) was determined to bring about a change in this norm. In April 2014, he was on his way to the PRISM ${ }^{1}$ office located at the Government Vocational Higher Secondary School for Girls, Nadakkavu in Kozhikode, Kerala. This school, barely a kilometer away, was the first to bear the fruit of his determination. He was on the way to attend the board meeting of the PRISM committee convened by Mr. A. Pradeep Kumar, the local Member of the Legislative Assembly (MLA) for Kozhikode. The efficient implementation in redeveloping a government school by a family foundation, earned Mr. Kottikollon many accolades from the public, media as well as the Kerala government, which showed a keen interest to scale up the project to other government schools in the state. Mr. Kottikollon himself was very interested in making a wider impact through such projects to bring quality education to students in other government schools. Mr. Pradeep Kumar had convened the board meeting to discuss the scaling up plans. As Mr. Kottikollon's car waited at a traffic signal, he began contemplating on the experience he had had so far, and wondered what would be the most appropriate role that he and his family foundation could play in the long run and the model that could be used to scale.

\section{The PRISM project}

Poor infrastructure along with poor quality of education at government schools in Kozhikode was a matter of concern for Mr. Pradeep Kumar (the local MLA). On a personal initiative of Mr. Pradeep Kumar, a project titled 'Promoting Regional schools to International Standards through Multiple interventions' (PRISM) was initiated on a trial basis in the Government Vocational Higher Secondary School for Girls Nadakkavu, in an attempt to improve the deteriorating state of these schools. PRISM was to target nine diverse areas of the school: school environment and ambience; learning aids; library and laboratories; students' personality development; creativity and innovation; building and physical infrastructure; teacher quality enhancement; stakeholder involvement; and school performance measurement and control system.

A newspaper reporter brought PRISM to the attention of Mr. Kottikollon - an established businessperson in Dubai and a native of Kozhikode. The project was born out of a social development project report of some MBA students of Indian Institute of Management Kozhikode (IIMK) ${ }^{2}$ titled as 'A project for improving quality of government schools to global standard'. Some of the other key stakeholders for this project alongside IIMK and Kerala government were the Regional Science Center Calicut, CWRDM ${ }^{3}$ and NIT $^{4}$ Calicut $^{5}$. The report was forwarded to Mr. Pradeep Kumar and the Planning Board of the Kerala Government. With a financial outlay of INR 45 million $^{6}$, the project aimed at addressing broader issues of deteriorating educational standards in the government schools of Kerala. 


\section{Education sector in India}

As per the Indian constitution, free and compulsory education is provided as a fundamental right to children between the ages of 6 and 14. Ever since independence, India had made gradual, but steady increase in literacy rates as shown in Exhibit 1. Both the governments (i.e. center and the state) and private sector played a significant role in education, with the latter enrolling around $30 \%$ of students in the 6-14 age groups (Joshua, 2014). India followed the 10+2 years of education model, with board examinations conducted at the end of 10th and 12th year of education.

The initiative by the Government of India (GoI) named 'Sarva Shiksha Abhiyan' (SSA) or 'Education for All' achieved unparalleled success in India by catering to over 200 million children, making it one of the largest elementary education programs in the world (World Bank, 2015a). Over 24 Indian states achieved universal primary enrolment. The program also ensured greater enrollment of girls in primary schools (less than 10 years old). However, the high enrolments in primary schools had not translated into corresponding successful outcomes with regard to secondary (10-16 years old) and higher secondary education (16-18 years old) levels. For instance, while over 95\% of India's children attended primary school, only $44 \%$ of them completed secondary education (World Bank, 2015a). The statistics became more acute for enrolment in tertiary education beyond schooling. According to World Bank estimates, only 1 in 10 Indian students had access to higher education opportunities (World Bank, 2011).

The government schools in India, enrolling close to $70 \%$ of primary and secondary school students, faced increasing number of problems. In 2013, a survey on the implementation of Right to Education (RTE) Act, carried out across 780 government schools in 13 major states revealed that over $30 \%$ of the schools did not have toilets leading to high dropout rates among girl students (Angre, 2013). Less than 5\% of the schools had the entire nine infrastructure related facilities mandated under the RTE Act (Sinha, 2013). Further, teacher absenteeism was high in government schools. According to a World Bank survey, 25\% of government school teachers (at the primary level) were regularly absent from work and only 50\% of teachers were actually engaged in the act of teaching while at work (World Bank, 2015b). The quality of education in government schools had also been a serious area of concern. For instance, the Annual State of Education Report (ASER) in 2013 revealed that the percentage of class III government school students who could easily read and comprehend class I text books comprised of only $32 \%$ per cent. Similarly, only $18.9 \%$ class III students in government schools were able to do basic subtraction (Down to Earth, 2014).

About $25 \%$ of all students who enrolled for schooling went to private schools. Even in the rural areas, the percentage increased from $18.7 \%$ in 2006 to $25.6 \%$ in 2011 (EY \& FICCI, 2014). The idea of free tuition, textbooks, uniform and meals was not working in government schools, when both learning and teaching efforts in private schools were found to be far superior. However, education was very expensive for majority of Indians (Kingdon, 2017). According to a National Sample Survey Office (NSSO) report, between 2008 and 2014, the average annual private expenditure for education shot up by a staggering $175 \%$ to INR 6,788 per student (Thomas, 2015). With 800 million citizens below the age of 35 years, there was thereby, a dire need for improving the status of government school education, in order to better skill a larger percentage of students who could not afford private schools (Podar, 2017).

The state of Kerala had ranked top amongst Indian states on literacy and health standards for a number of years (Balaji, 2011). This was achieved owing to a combination of historical reasons including the social inclusion focus of its state governments, role of Christian missionaries and native princes, and social movements for uplifting deprived communities (Mathew, 1999). In 1990, India's 
National Literacy Mission declared total literacy in the state, a first among Indian states (Mathew, 1999). Kerala also became the first state to achieve 100\% primary education in 2016 (Philip, 2016). Despite these laurels, infrastructure and quality of many government schools were not on par with the global standards. The PRISM project emanated from this.

\section{F\&SF and PRISM Project}

During an interview with Mr. Kottikollon, a newspaper reporter highlighted the expected society wide impact of the PRISM project. Mr. Kottikollon considered this as an opportunity to give back to his birthplace by making an impact on the education sector. However, he was confused as to the extent and nature of the role he had to take in this specific initiative. For him, it was a choice between a charity approach and a venture philanthropic approach (refer Grossman et al., 2013 for details on the differences between the two approaches). He also had to make an implementation vehicle choice between his family foundation and another NGO. Based on his understanding of CSR initiatives and charity donations made by different individuals and organizations in India, he realized that in order to make a sustainable long-term impact, a professional approach involving corporate business practices was needed. Wanting to set a pioneering example in philanthropic investment into a government initiative in Kerala, by approaching the project in a professional and scalable manner, Mr. Kottikollon believed that delivery of quality education did influence the economic and social disparity between the rich and the poor. Further, he believed that government schools additionally contributed to this disparity by delivering poor quality of education as compared to private schools.

Mr. Kottikollon started the project by instructing his family foundation (F\&SF) to undertake a due diligence process to understand the project proposal put forward by Mr. Pradeep Kumar (MLA). The study revealed that there were many government schools in Kerala in a dilapidated state and in need of rejuvenation. He believed that if he could set a model by redeveloping a government school, then other such initiatives could be triggered. Subsequently, he chose the Government Vocational Higher Secondary School for Girls, Nadakkavu, as it was specifically for girls. He firmly believed that education of the girl child was of utmost importance as that had the maximum impact on family and community. The famous proverb by Brigham Young "You educate a man, you educate a man. You educate a woman, you educate a generation" also reverberated in his thoughts. To set an example, he decided to make the entire financial investment needed for the project from his personal finances, based on a due diligence done by his team. In order to ensure close monitoring and professional implementation, he involved his family foundation to lead the project. The initial investment by F\&SF was INR 160 million and the planned investment for the second year was INR 100 million.

\section{History of F\&SF}

F\&SF was established in 2007 in Dubai, UAE, by husband-wife team of Faizal and Shabana Kottikollon, in line with their belief in social responsibility and upliftment of underprivileged in society. Along with Faizal and Shabana, Dr. Joseph was employed as the full-time Global head of the foundation (Exhibit 2). The foundation actively supported numerous charitable initiatives throughout India and the UAE. Mr. Kottikollon, who earlier founded the KEF Company, approached business by stressing on holistic development of human beings. The vision statement and value system of KEF (Exhibit 3) was testimony to the close working relationship between F\&SF and KEF. This focus dominated the creation of F\&SF which leveraged professional expertise of all KEF verticals for its philanthropic projects through the Board of Directors (refer Exhibit 4 and 5). KEF was incorporated on April 8th 2012 at the Dubai International Financial Centre (DIFC). F\&SF was registered in India under Section 25 of the Company Act in the year 2012 as a Not-For-Profit (NFP) for charitable purposes with activities focused on key humanitarian areas like - education, housing, health, 
sustainable livelihood, humanitarian assistance and youth development. Although F\&SF was involved in a number of charitable activities across UAE and India, their prior experience was mostly restricted to funding potential bright and needy students or in healthcare ${ }^{7}$. It had not yet undertaken large-scale school turnaround projects particularly in collaboration with governments.

F\&SF, in UAE, provided the Shabana and Faizal Scholarship, an Endowment Fund at American University of Sharjah (AUS). This scholarship was to support bright and needy students whose finances precluded them from studying at AUS. Shabana and Faizal Scholarship at AUS was a generous gift of AED 5 million ${ }^{8}$. The Sheikh of Sharjah offered a matching grant, to support this initiative ${ }^{9}$. Further, the F\&SF also provided support for Al Noor Training Center for Children with Special needs. This training center aimed to provide all individuals with special needs the same opportunity, regardless of background, through professional training and care to realize their potential, with the aim of integrating them into the wider community. The center offered a range of services like occupational therapy, physiotherapy and autism treatment ${ }^{10}$. Under healthcare, F\&SF offered AED 1 million for Alzheimer's and Breast Cancer Research to the University of Sharjah's Cancer Research Center ${ }^{11}$. The foundation also took up service towards the expatriate Indian community along with other Indian philanthropists in setting up an Indian Community Centre for Individuals with Disability at Dubai. Through its 'KEF Run for Haiti' initiative, F\&SF undertook a one-time charity marathon to raise money, clothes and toys besides donating AED 1 million $^{12}$ on behalf of the company, while AED 151,094 was raised from other individuals for victims of Haiti earthquake.

In India, F\&SF is based out of Bangalore. Besides the PRISM project mentioned earlier, it extended its UAE experience by supporting the K E Safiya Autism Center, Mahe, India, a research based multispecialty resource center comprising of a school with special needs, vocational education and rehabilitation center. Similarly, F\&SF also supported a home for destitute women run by Care and Caress Society, Kannur, in Kerala, Mr. Kottikollon's home state. F\&SF also offered aid to a hostel for orphan and tribal girls based out of Kasargod, in Kerala and supported young budding football players through an NGO Sports \& Education Promotion Trust (SEPT). SEPT, incepted in 2004, and based in Kozhikode, set up 41 centers called 'football nurseries' spread across 11 districts in Kerala, identifying talented children from rural, tribal and coastal areas living in difficult conditions with targeted sport initiatives. In a non-conventional approach to bring children back to school, this football nursery made it compulsory for children to regularly attend school (mostly government and missionary run schools) to qualify for football coaching. It was only with this prior experience that F\&SF finally entered into a large-scale education sector project in collaboration with the government.

\section{Challenges before F\&SF in PRISM}

Mr. Kottikollon wondered how much of F\&SF's experience in philanthropy and charity was going to help it plan and execute the PRISM project successfully. Confronted with the challenge of improving the overall quality of education in government schools and with this background, how could the role of a private philanthropy like F\&SF be significant and effective?

The PRISM project outlay of INR 160 million was one of the largest projects ever undertaken by F\&SF. The PRISM Committee for the project had Mr. Pradeep Kumar (MLA) as the Chairman along with senior faculty of IIMK and Mr. Kottikollon himself, bringing diverse perspectives, expert advice and strong networks.

Interestingly while most other projects of F\&SF had an NGO partner, with PRISM, it was direct and hands-on. Dr. Joseph (F\&SF) and his team were on site as part of the school development team to oversee the progress right from due diligence. F\&SF had signed a five year Memorandum of 
Understanding (MOU) with PRISM. Additionally, there were other resources from KEF (the holding company), to draw upon as and when required at no extra cost. The entire project was broken into phases with the PRISM team focusing on specific aspects of the project in each phase.

The first phase focused on infrastructure development. With a donation of 150 used computers from Infosys Limited, smart classrooms were created along with eight new overhead projectors. Funds were allocated for developing an AstroTurf playground. A Heritage Maintenance Fund of INR 2.5 million was allocated to maintain older buildings of the school. Simultaneously, work progressed on the building using a state-of-art civil engineering pre-cast concrete technology with the support of KEF infrastructure vertical. For the new building, world-renowned Scottish architect, William Cooper was consulted for designing the building along with his Indian counterpart Tony. F\&SF completed the project construction in record two months. Although 300 workers were on campus, no classes were disrupted for the 2500 students of the school for any length of time. Other infrastructure upgradation included a 300 seater canteen and walkways that could be used by locals as walking and jogging pathways early in the morning before classes began. Modern facilities like indoor games court, science laboratories, change rooms, nurse rooms and mural paintings added to the aesthetics of the school.

In the second phase, academic and curricular issues were addressed. A two-day 'transformational leadership program for educational excellence' was designed for school teachers' capacity building at IIMK where topics of creativity, glimpses of world class schools, learning objectives and assessment were discussed ${ }^{13}$. F\&SF sponsored all teachers participating in this program. The local government also promised the school authorities and administration that these teachers would not be further transferred to other schools, as experienced resources like them were needed at least for the next three to four years to help PRISM achieve its objectives. A healthy balance of classroom and physical education was created with training in hockey, karate, theater and music in the curricula.

Additionally, tangible impact measurement parameters were created for the investment. There were short-term as well as long-term goals. Short-term yearly goals included 100\% success of the students of the school in academic examination, target number of high grades in subsequent board examination, and certain number of activities being completed by the school within the academic year. The long-term goals of a 5-year vision included making the school one of the top 10 schools in the country on different parameters, enabling at least $30 \%$ of students to join professional courses, and replicating the Nadakkavu school model in other government schools in Kerala and across the country. One short-term goal that was achieved in the first year was 100\% increase in the number of students getting A1 grade (highest possible) in board examinations ${ }^{14}$. The experience that students shared about studying in the school pre- and post-redevelopment phase clearly highlighted the distinct mind-set change that had occurred. One student said in a television discussion "we now feel that we are studying in an international school, and feel a lot more confident ${ }^{28}$ ".

As a businessman, Mr. Kottikollon was worried about building self-sustainability in the long run into the project. An example for this would be the operation of kitchen in the school. Across government schools in India, there was a program called 'Mid-day meal scheme' aimed at providing free lunch to students. The government allocated a fixed amount per student per meal. At Nadakkavu School, in addition to the government allocated fixed amount, Mr. Kottikollon provided additional funding so that students got more nutritious food. In order to ensure that the kitchen is able to sustain on its own without the support of F\&SF, state-of-the-art facilities of the kitchen was used to cook food on a commercial scale. F\&SF partnered with Kudumbashree (a women-empowerment project of Government of Kerala ${ }^{15}$ ) for this initiative. Under this initiative, during the spare time available (i.e. 
after the food was cooked for the students in school), packaged food was produced for commercial sale. Using the money earned from the commercial sale, funding support from F\&SF would be substituted, leading to a self-sustaining model.

Finally, an exit strategy for F\&SF from this project was planned. F\&SF was to maintain the infrastructure of the school for five years and support the school management in achieving the longterm goals stated earlier. Over the 5-year period, F\&SF had planned a phased delinking from the project, by handing over key responsibilities to the PRISM committee and school management.

\section{Future Plans}

Mr. Kottikollon and his family foundation made a five-year commitment to the Government Girl's High School Nadakkavu. While Mr. Kottikollon was aware of the larger impact that F\&SF could make by scaling up its government school project to 100 more schools, he was not sure if replication of the same model of redevelopment to other schools in Kerala and across India would be the best option. With the learning from the Government High School Nadakavvu, he had multiple options running in his mind when it came to the nature of involvement he and his family foundation could have in replication initiatives. Was F\&SF involvement in the Nadakavvu School that of a venture philanthropy? Could the same model be used for scaling up to other schools?

\section{Option 1: Same level of personal involvement and role of family foundation}

One of the options ahead for Mr. Kottikollon was to adopt the same approach that he took for the Nadakkavu School and replicate it in other government schools across Kerala.

Option 2: Limited personal investment, but the family foundation continues to play the primary implementation agency role

This option required $\mathrm{F} \& \mathrm{SF}$ to raise finances from other philanthropists and the large diaspora from Kerala staying abroad. F\&SF could continue to act as implementation agency.

\section{Option 3: F\&SF as a consultant in implementation}

Another option before F\&SF was offering consulting support in the form of expertise and guidance, without making any commitments of finance for the projects. Other NGOs or government could act as the funding and implementation agency in this case.

\section{Option 4: Opting for a charity based model}

This option was to approach other government school redevelopment on a charity basis. F\&SF could just make charitable personal investment in the individual project, and the government or another NGO could oversee the implementation of the project with no role for F\&SF.

\section{Option 5: Phased de-linking of both personal investment and family foundation}

In the light of multiple bureaucratic restrictions faced in Nadakkavu school project, F\&SF could plan for a phased de-linking of both Mr. Kottikollon's personal investments and that of his family foundation from the present as well as future projects.

Mr. Kottikollon knew that the decision was complex. Thus, immersed in these thoughts, his car reached the entrance of the re-developed Nadakkavu School for the PRISM meeting to discuss scaling up. 


\section{Annexure 1}

\section{Philanthropy in India}

Philanthropic donations accounted for 0.6 percent of India's GDP. In comparison, the U.S. gave 2.2 percent, the UK 1.3 percent, and Canada 1.2 percent. However, compared to emerging market peers like Brazil (0.3 percent) and China (0.1 percent) India fared better (Sheth, 2010). Individual and corporate donations made up only 10 percent of charitable giving in India. The remaining philanthropy aid came from foreign organizations and the government. Nearly 65 percent of the donations came from India's central and state governments mostly focused on disaster relief. In contrast, nearly three-fourths of all philanthropy in the US was undertaken by individuals (Sheth, 2010).

India, however, had a long tradition of philanthropic giving. Until the 1800s, giving in India was largely religious in nature and motivated by the search for individual salvation. Later, philanthropy began to be directed towards social causes such as education and women's rights. Throughout the 20th century, leading Indian industrialists established foundations and other charitable institutions of national importance (Agrawal and Sahasranamam, 2016).

India had the highest growth in HNWIs amongst BRIC economies in early 2000s. However, the relatively recent nature of accumulation of wealth by these individuals inhibited philanthropic investments. Globally, it was observed that it took 50 to 100 years for philanthropic markets to mature. In India, as the wealth accumulation became significantly higher in the post-liberalization (post-1991) era, many of the wealthy were not eager to part with their money for philanthropy. An analysis done by Bain \& Company of 30 high-net-worth individuals in India showed that they contributed, on average, just around one-fourth of 1 percent of their net worth to social and charitable causes (Sheth, 2010).

\footnotetext{
${ }^{1}$ PRISM - Promoting Regional schools to International Standards through Multiple interventions

${ }^{2}$ A premier management institute in India under the Ministry of Human Resources Development of Government of India and set up in collaboration with the state government of Kerala

${ }^{3}$ CWRDM - Centre for Water Resources Development and Management

${ }^{4}$ NIT - National Institute of Technology

${ }^{5}$ Calicut was the historical name of the city of Kozhikode and continues to appear in many registered bodies

${ }^{6}$ Government funding to the tune of INR 20 million and INR 10 million (split into two tranches) supplemented with INR 15 million from NGOs and private corporations under their CSR activities

${ }^{7}$ Interview with Dr. Joseph, Head, Faisal and Shabana Foundation dated 16.05.2014

${ }^{8}$ American University of Sharjah, "AED 5 million endowment to establish the Shabana and Faizal scholarship at AUS", accessed May 10, 2014, http://www.aus.edu/news/article/117/aed_5 million_endowment to_establish the shabana_and_faizal_scholars hip at aus

${ }^{9}$ Interview with Dr. Joseph, Head, Faisal and Shabana Foundation dated 16.05.2014

${ }^{10}$ Al Noor, "Al Noor Training Centre", accessed May 10, 2014, http://alnoorspneeds.ae/

${ }^{11}$ Daiji World, "Sharing Entrepreneur Success - An Inspiring KEL Event”, January 22, 2013, accessed May 10, 2014 http://www.daijiworld.com/news/printer.asp?nid=161611

12 In US dollar terms, approximately $\$ 27000$

${ }^{13}$ Internal documents

${ }^{14}$ Media One, "Kerala Summit", accessed June 1, 2014, https://www.youtube.com/watch?v=IAdBdmR2aRg

${ }^{15}$ Kudumbashree, accessed June 1, 2014 http://www.kudumbashree.org/?q=home
} 


\section{References}

Agrawal, A. and Sahasranamam, S. (2016) 'Corporate social entrepreneurship in India', South Asian Journal of Global Business Research, 5(2), pp. 214-233.

Angre, K. (2013) Many government schools have no toilets, drinking water, and boundary walls, survey reveals, NDTV. Available at: http://www.ndtv.com/india-news/many-government-schoolshave-no-toilets-drinking-water-and-boundary-walls-survey-reveals-526609 (Accessed: 20 May 2016).

Balaji, J. (2011) 'Kerala tops in literacy rate, health services', The Hindu, 22 October.

Down to Earth (2014) Government schools imparting poor quality education. Available at: http://www.downtoearth.org.in/news/government-schools-imparting-poor-quality-education-43292 (Accessed: 20 May 2016).

EY and FICCI (2014) Private sector's contribution to K-12 education in India. Available at: https://www.ey.com/Publication/vwLUAssets/role-of-private-sector-on-K-12-education-inIndia/\$FILE/EY-role-of-private-sector-on-K-12-education-in-India.pdf (Accessed: 19 July 2017)

Grossman, A., Appleby, S. and Reimers, C. (2013) Venture Philanthropy: Its evolution and its future, Harvard Business School, Background Note 313-111, http://www.hbs.edu/faculty/Pages/item.aspx?num=44847

Joshua, A. (2014) 'Over a quarter of enrolments in rural India are in private schools', The Hindu, 16 January.

Kingdon, G. (2017) The price of studying in private schools, India Today. Available at: http://indiatoday.intoday.in/story/private-schools-price-studying/1/992849.html (Accessed: 19 July 2017).

Mathew, E. (1999) 'Growth of literacy in Kerala: State intervention, missionary initiatives and social movements', Economic and Political Weekly, 34(39), pp. 2811-2820.

Philip, S. (2016) 'First state to achieve 100\% primary education, but is there more to Kerala's feat?', The Indian Express, 13 January.

Podar, R. (2017) Analysis of private education in India and the way ahead, Your Story. Available at: https://yourstory.com/2017/04/private-education/ (Accessed: 19 July 2017).

Sheth, A. (2010) An overview of philanthropy in India, Bain \& Company. Mumbai. Available at: http://www.bain.com/Images/India_Sheth_Speech.pdf (Accessed: 4 July 2018).

Sinha, S. (2013) Condition of government schools in India: A shocking truth, Millennium India Education Foundation. Available at: http://mief.in/condition-of-government-schools-in-india-ashocking-truth/ (Accessed: 20 May 2016).

Thomas, M. (2015) The cost of getting a (decent) education in India is skyrocketing, Quartz India. Available at: https://qz.com/445500/the-cost-of-getting-a-decent-education-in-india-is-nowstaggering/ (Accessed: 20 May 2016).

World Bank (2011) Education in India. Available at: http://www.worldbank.org/en/news/feature/2011/09/20/education-in-india (Accessed: 20 May 2016).

World Bank (2015a) Educating India's children. Available at:

http://www.worldbank.org/en/country/india/brief/educating-india-children (Accessed: 20 May 2016).

World Bank (2015b) Teachers skipping work. Available at:

http://web.worldbank.org/WBSITE/EXTERNAL/COUNTRIES/SOUTHASIAEXT/0,,contentMDK:2 0848416 pagePK:146736 piPK:146830 theSitePK:223547,00.html (Accessed: 20 May 2016). 


\section{Exhibits}

\section{Exhibit 1: Literacy rate in India}

\begin{tabular}{|r|r|r|r|}
\hline \multicolumn{1}{l|}{$\begin{array}{l}\text { Census } \\
\text { Year }\end{array}$} & \multicolumn{1}{l|}{$\begin{array}{l}\text { Literacy } \\
\text { rate }\end{array}$} & \multicolumn{1}{l|}{ Male } & \multicolumn{1}{l|}{ Female } \\
\hline 1951 & 18.33 & 27.16 & 8.86 \\
\hline 1961 & 28.3 & 40.4 & 15.35 \\
\hline 1971 & 34.45 & 45.96 & 21.97 \\
\hline 1981 & 43.57 & 56.38 & 29.76 \\
\hline 1991 & 52.21 & 64.13 & 39.29 \\
\hline 2001 & 64.83 & 75.26 & 63.67 \\
\hline 2011 & 74.04 & 82.14 & 65.46 \\
\hline
\end{tabular}

Source: Census of India (http://censusindia.gov.in/2011-provresults/data_files/india/Final_PPT_2011_chapter6.pdf)

\section{Exhibit 2: Organizational structure of Faizal and Shabana Foundation (F\&SF)}

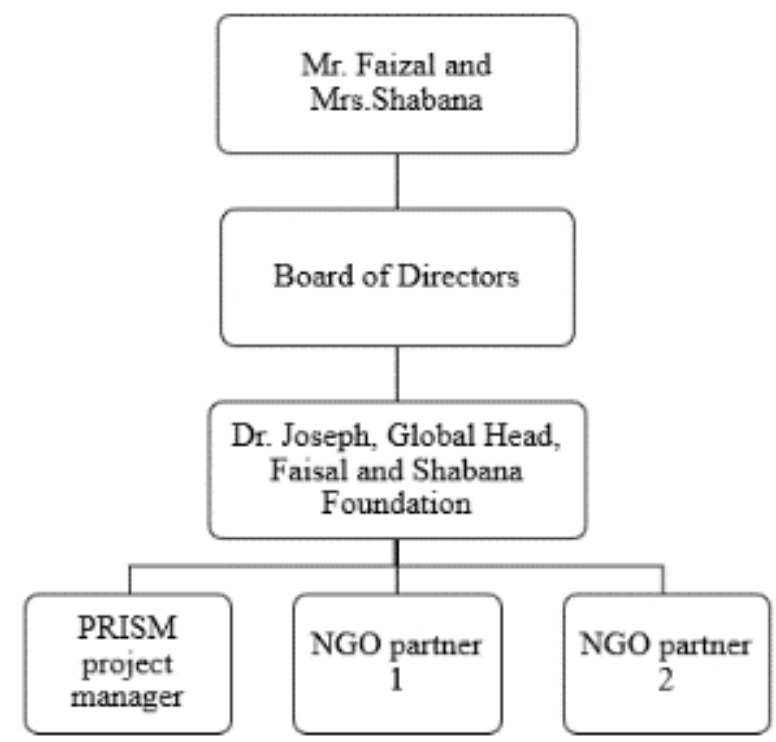

Source: Created by the authors' based on the discussions with Dr. Joseph

\section{Exhibit 3: Vision statement and value system of KEF}

Vision statement: "Together, we make a difference to people and societies by improving their quality of life"

Value system: The company adhered itself to a four pillar value system

- Innovation: We bring unique solutions to the problems we solve.

- Excellence: We pave the way for people and societies to excel.

- Integrity: We build relationships based on mutual respect, and always behave with integrity.

- Humility: We enjoy working collaboratively and care about people and environment we live in.

Source: http://thekefcompany.com/en/content.aspx?gid=23 accessed May 10, 2014. 
Exhibit 4: Positioning of F\&SF within the KEF Company

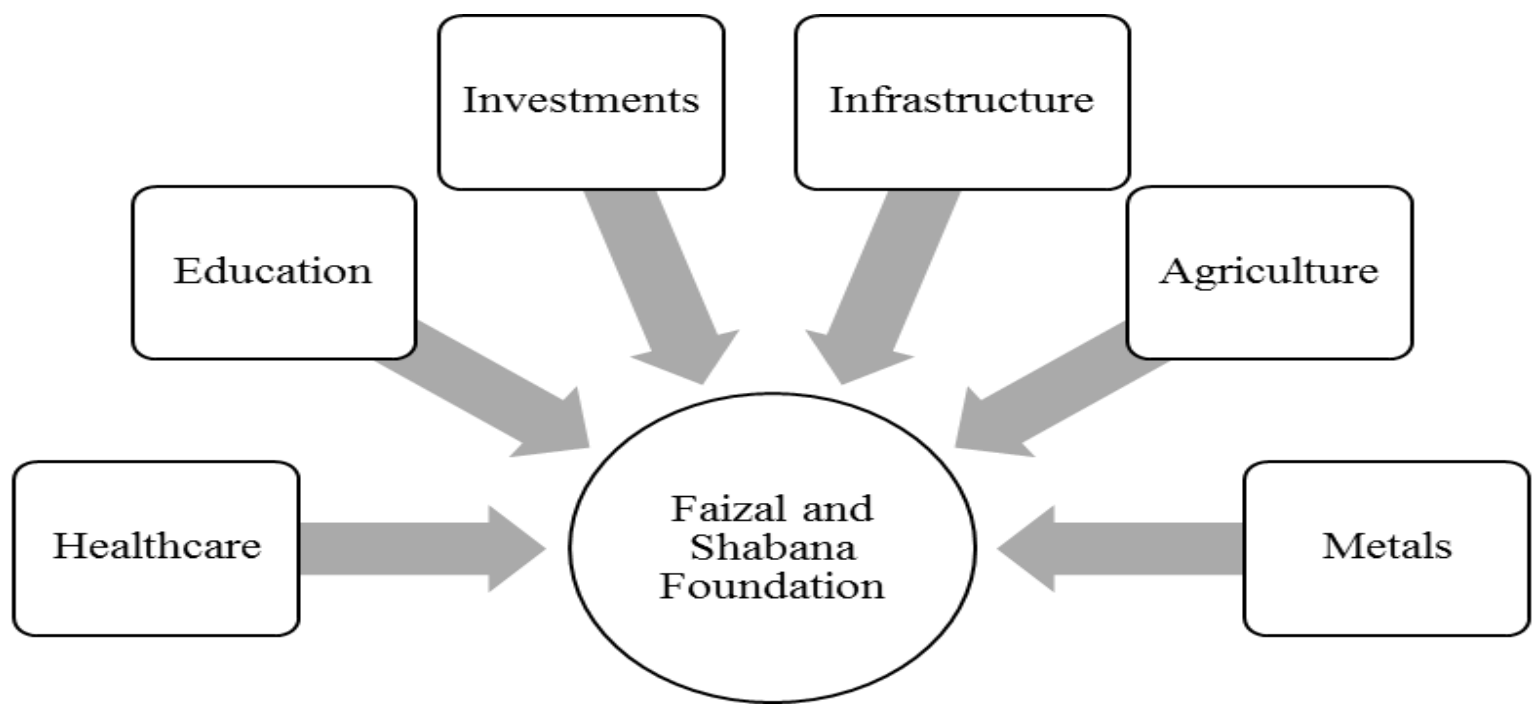

Source: Created by the authors' based on the discussions with Dr. Joseph

Exhibit 5: Organizational holding structure of KEF Company Ltd.

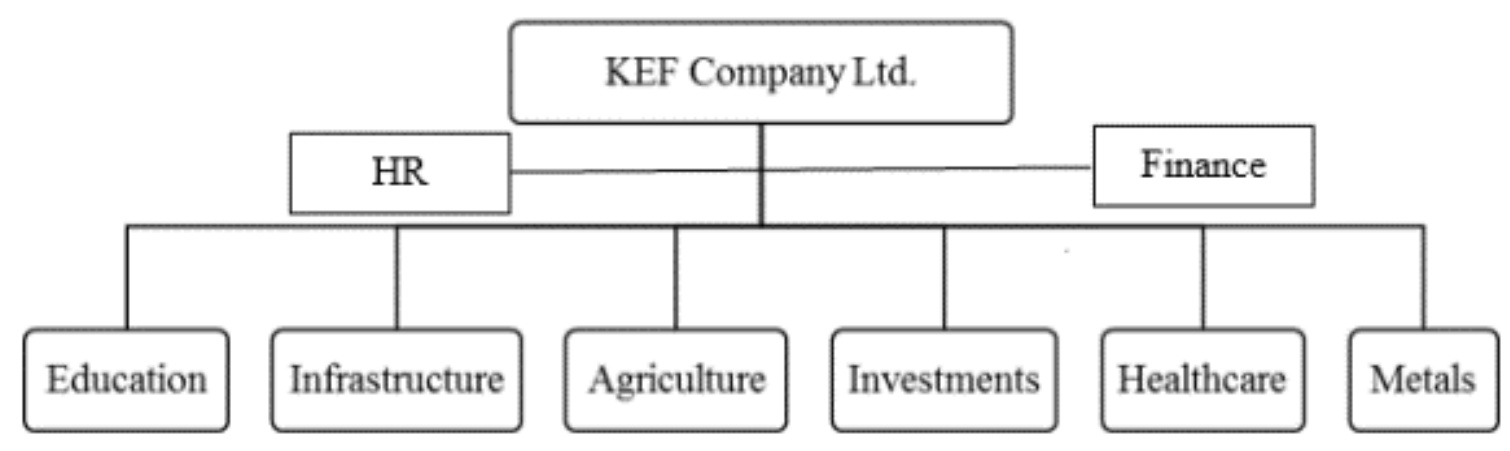

Source: Created by the authors' based on the discussions with Dr. Joseph 